certain cultural peculiarities and the spores are readily killed by mild heat.

The full papers of the symposium will appear in a fortheoming issue of the Journal of Applied Bacteriology.

\section{PROTECTION AGAINST IONIZING RADIATIONS}

$\mathrm{T}$ HE rapidly widening range of applications of atomic energy and artificial radioactivity and the increasing concern and speculation on the part of the general public concerning the biological effects of ionizing radiations make the publication of the latest recommendations of the International Commission on Radiological Protection* an event of major importance. The Commission functions under the auspices of the International Congress of Radiology, which held its seventh meeting in Copenhagen in 1953.

The history of radiation protection extends back as far as 1921, to the inauguration in the United Kingdom of the British X-ray and Radium Protection Committee working under the auspices of the British Institute of Radiology, and in the United States of the Röntgen Ray Protection Committee. The formation of these and other national committees led to the first International Commission on Radiological Protection in 1928. Since that time the Commission has met at regular intervals, and its expanding sphere of interest may be judged by comparing the present 92-page report with the last recommendations issued, in 1950, comprising some eight pages in print. The British X-ray and Radium Protection Committee has recently handed over its responsibility to other committees meeting under the auspices of the Ministry of Health and the Medical Research Council, and these bodies have set up a joint Radiological Protection Service to advise users in the United Kingdom on all matters relating to protection.

The present Commission includes members from ten nations and has five sub-committees dealing respectively with the permissible dose for external radiation, the permissible dose for internal radiation, protection against $X$-rays up to three million volts, protection against $\mathrm{X}$-rays above three million volts and against heavy particles, and the disposal of radioactive wastes and handling of radioactive isotopes. The report gives the recommendations of the first four of these ; the report of the sub-committee on the handling and disposal of radioactive materials will be published later as an addendum.

In formulating its recommendations, the Commission recognizes that any significant departure from the environmental conditions in which man has evolved may strictly entail some hazard. Since no radiation-level above the natural background due to terrestrial radivactivity and cosmic rays is absolutely safe, the problem is to choose a practical level that involves a negligible risk. The concept invoked here is that of a "maximum permissible weekly dose" of radiation or a "maximum permissible body lurden" of a radioisotopo such that if exposure at this level were continued indefinitely, no appreciable bodily injury would be expected to result during the lifetime of the exposed individual. The recommendations

* Recommendations of the International Commission on Radiological Protection (Revised December 1, 1954). British Journal of Radiology Supplement No. 6. Pp. $x+92$. (London: British Institute of Badiology, 1955.) 10s. 6d. with paper cover, 12s.6d. with cloth cover. are primarily intended to apply to the occupational exposure of personnel forming only a small fraction of the community, and in such circumstances genetic changes affecting the race as a whole are not considered the limiting factor. The report suggests a reduction of all permissible levels by a factor of 10 to take account of possible genetic effects where exposure of a large population is involved.

Past recommendations of the Commission have been chiefly concerned with the establishment of a maximum permissible weekly dose in röntgen units for whole-body exposure to $\mathrm{X}$ - or $\gamma$-radiation, and in 1950 this was fixed at $0.3 \mathrm{r}$./week. The subcommittee on the permissible dose for external radiation does not now recommend any change in this basic value for $\mathrm{X}$ - and $\gamma$-rays up to $3 \mathrm{MeV}$., which remains at $0 \cdot 3 \mathrm{r}$./week, corresponding approximately to an absorbed dose in soft tissue of $0.3 \mathrm{rad} /$ week. Maximum permissible levels for other types of ionizing radiation are also considered.

Some confusion may result from the multiplicity of units used in the report for the expression of radiation dose or radiation absorption in tissue. This arises in part from the fact that shortly before its publication the International Commission on Radiological Units recommended that the rad should be used wherever possible as the unit of absorbed radiation dose. This unit is equal to an energy absorption of $100 \mathrm{ergs} / \mathrm{gram}$. Because of the varying biological effectiveness of different types of radiation, it is found necessary to introduce a further unit-the rem-which is defined on p. 19 as "the absorbed dose of any ionizing radiation which has the same biological effectiveness as $1 \mathrm{rad}$ of $\mathrm{X}$-radiation ." This appeurs to be at variance with previous definitions of the rem as that dose which has the same biological effectiveness as 1 röntgen of X-rays. The use of the rem might have been avoided had the Commission chosen to recommend that the maximum permissible dose for heavy ionizing particles should be that for $X$ - or $\gamma$-rays divided by the relative biological effectiveness of the radiation in question. It must be pointed out that the relative biological effectiveness for any given radiation may depend on the type of biological effect studied.

On p. 17 it is assumed that the tissue dose in rads is approximately numerically equal to the dose in röntgens in the tissue concerned. It should perhaps be emphasized that this assumption is only valid in soft tissue where the mean atomic number is nearly equal to that of air. Some clarification of these issues would be welcome in future recommendations of the Commission.

Radiobiological studies have demonstrated that certain organs of the body-notably the skin, bloodforming organs, gonads and eyes-are particularly vulnerable to radiation damage. Special consideration is therefore necessary with highly non-uniform distributions of radiation dose such as may be encountered in exposure to particulate radiation. For this purpose, the concept of the 'critical organ' is introduced; by this is implied the organ of the body which under the conditions of the exposure receives the dose that results in the greatest bodily damage. The criterion used in establishing maximum permissible levels is that the dose absorbed by the critical organ shall not exceed $0.3 \mathrm{rad} / \mathrm{week}$ of $\mathrm{X}$ - or $\gamma$-rays or an equivalent amount of other radiation.

The idea of the 'critical organ' is fundamental to the report of the sub-committee on the permissible 
dose for internal radiation, which considers the hazards due to ingestion or inhalation of radioactive materials. Taking account of the non-uniform distribution of radioactive material in the body, maximum permissible levels of concentration in air and drinking water are quoted for ninety-one isotopes or mixtures of isotopes. For most of these, the criterion used is that of the absorbed dose in the critical organ, the calculations being based on a "standard man" in whom all characteristics are chosen to be those representative of the average man. In the case of $\alpha$-emitting radioisotopes that become localized in bone however, the levels are based on a direct comparison with radium. A large accumulation of human experience is available regarding the effects of ingested radium in man, and the maximum permissible body burden of this element has long been fixed at $0 \cdot 1 \mu \mathrm{c}$.

With many other isotopes, human data are usually completely lacking, and distribution and turnover must be estimated in other ways, for example, from the results of animal experiments. The sub-committee acknowledges that these calculations are often only approximate. Moreover, the figure of $0.3 \mathrm{rad} /$ week applies properly to whole-body radiation, and its extension to partial-body irradiation of a critical organ may entail a considerable safety factor-a factor which may, however, be offset by irregularities in the distribution of radioactivity in the tissues of the critical organ itself, especially at the histological level. It is probable that many of the values quoted in this section may have to be revised as more detailed data become available regarding the effects of partial body irradiation and the non-uniform distribution of radioisotopes in tissue. Meanwhile, they form a valuable working guide for persons working with radioactive materials, though some may regret that the data were not presented in a more abbreviated and simplified form.

In the report of the sub-committee on protection against X-rays up to $3 \mathrm{MeV}$, detailed recommendations are given for the planning, surveying and monitoring of new X-ray installations. Principles to be followed in establishing general working conditions in such installations are outlined and the special requirements of medical diagnostic, medical therapeutic, and non-medical units are discussed separately. The hazards arising from non-useful sources of $X$-rays (eathode ray oseillographs, television tubes, transmitting valves, etc.) are also discussed. A valuable appendix provides data on the absorption of $\mathrm{X}$ radiation in various shielding materials, and the protective barrier requirements of different types of installation.

Finally, the sub-committee on protection against $X$-rays above $3 \mathrm{MeV}$. and against heavy particles recommends a maximum permissible weekly dose of $0.3 \mathrm{rad} /$ week for $\mathrm{X}$-rays above $3 \mathrm{MeV}$., and $0.03 \mathrm{rad} /$ week for neutrons in the energy range $0.025 \mathrm{eV}$.$10 \mathrm{MeV}$., assuming a relative biological effectiveness of 10 for neutrons in the critical organ-in this case the eyes. Values of neutron flux corresponding to the maximum permissible dosage rate at different energy levels, and relative biological effectiveness figures for different types of particulate radiation are specified.

The report is an impressive example of international co-operation and should receive the serious attention of all who are concerned in the production, handling, and use of radioactive materials and machines producing ionizing radiations. E. H. BELCHER

\section{OBITUARIES}

\author{
Prof. G. F. Shirras
}

Prof. George Findlay Shirras, who died on June 23, came of an Aberdeen business family, and was educated at Robert Gordon's College in Aber. deen and at the University of Aberdeen, where he distinguished himself outstandingly in economics. Choosing an Indian career, he joined the Indian Educational Service, and at the early age of twenty. four he became professor of economics in Dacca College and was elected a Fellow of the University of Calcutta. For thirty years thereafter he held a succession of posts, doubling some of them. During 1910-13 he served in the Finance Department of the Government of India, and during 1914-21 he was director of statistics, as well as reader in economics in the University of Calcutta. He next spent five years as director of the Labour Office of the Bombay Government, and thereafter he was principal and professor of economics in Gujarat College, University of Bombay, until he retired in 1939. He then undertook the headship of the Economics Department in University College, Exeter, for the period of the War. $\mathrm{He}$ worked for a time in the Control Commission for Germany as controller-general of the Finance Division.

Work more to his taste awaited him elsewhere. He held the professorship of economics for a year in Trinity College, Dublin, and in the following vears he worked as visiting professor and lecturer in several American universities, notably at Illinois, Florida and Cornell Universities.

Shirras wrote and published on a large scale and with authoritative effect in the field of statistics. Two weighty books sprang from his Indian experience -.."Indian Finance and Banking" and "The Science of Public Finance", and also "Some Aspects of Indian Commerce and Industry". Others of his publications were "Federal Finance in Peace and War" and "Planning towards Recovery". He undertook research and wrote on Sir Isaac Newton, being attracted by Newton's work at the Mint, and he contributed to the "Encyclopædia Britannica". A book entitled "The Burden of British Taxation" came out in 1943.

His enthusiastic spirit conceded nothing to advancing age or to his status of retirement. $\mathrm{He}$ may truly be said to have been the victim of his arduous concentration on work and his intense interest in problems and people. He was alert and responsive, whatever the occasion or the company, lucid and engaging in speech and gifted in writing. He wrote, moreover, a scrupulously clear and graceful hand. Large-headed, of striking features, and virtually bald, he had a rare distinction of appearance. Outside economics, his chief study was the Bible, especially the Psalms, and the Saints. Born a Presbyterian, he became an Anglican, and officiated frequently and acceptably as a lay preacher.

He died prematurely, it may justly be said, a little before his seventieth birthday. He died, as he would have wished, in harness, on his way to take part in the conference of the International Statistical Institute at Rio de Janeiro.

Shirras married Amy Zara, the only daughter of the late George MeWatters, who survives him. Of his two sons, Major Richard Shirras and Major Douglas Shirras, the latter was killed while serving in France with the Seaforth Highlanders. 